\title{
The clinical outcome comparison of ischemic stroke with and without atrial fibrillation
}

\author{
Rizaldy Taslim Pinzon, Fransiscus Buwana
}

Neurology Department, Faculty of Medicine, Duta Wacana Christian University, Yogyakarta, Indonesia

Received: 2019-03-15

Accepted: 2019-05-20

UDC: 616.1

\section{J Clin Med Kaz 2019;2(52):37-41}

Corresponding Author: Rizaldy Taslim Pinzon,

Wahidin Sudirohusodo 5-25, Yogyakarta, Indonesia,

55224. Tel.: +62 274563929

E-mail: drpinzon17@gmail.com

\section{Abstract}

Background: Atrial fibrillation increases the risk of stroke and is associated with poor stroke outcomes. The primary concern of this study was to compare the clinical outcome of ischemic stroke patients with atrial fibrillation and without atrial fibrillation.

Methods: This was a retrospective cohort study using secondary data from electronic medical record and electronic stroke registry of Bethesda Hospital Yogyakarta, Indonesia. The data was collected from 2017-2018. The presence of atrial fibrillation at stroke onset and during the acute phase was confirmed by a standard electrocardiogram. The primary outcomes of the study was in-hospital mortality, disability measured by modified Rankin Scale (mRS), and length of stay. We used SPSS 20 with significance level 0,05.

Results: Among 1688 patients with ischemic stroke, 45(2,67\%) had atrial fibrillation. $51,11 \%$ of patients with AF were males and $82,22 \%$ aged above 60 years. The mortality of stroke patients with atrial fibrillation group is eighteen patients $(40.0 \%)$, thirty seven patients $(84.4 \%)$ have poor functional outcome $(\mathrm{mRS} \geq 2)$ and have length of stay $6(0-41)$ days. Bivariate analysis showed stroke patients with atrial fibrillation group is significantly associated with higher inhospital mortality (RR: 2.11 ; 95\% CI: 1.09-2.22; p: 0.001), worse disability (RR: $2.09 ; 95 \%$ CI: 1.92-2.32; p: 0.001) and prolonged hospital stay (6 (0-41) vs 4 (0-14), p:0.001) than in stroke patients without atrial fibrillation group.

Conclusion: Atrial fibrillation is associated with stroke outcomes. Careful cardiac evaluation and appropriate treatment are needed to improve the poor outcomes in patients with ischemic stroke and atrial fibrillation.

Keywords: atrial fibrillation, ischemic stroke, comparison, clinical outcome

\section{ИШЕМИЯЛЫҚ ИНСУЛЬТТІ КЛИНИКАЛЫҚ НӘТИЖЕСІН ЖУРЕКШЕ БУЛКІЛДЕУІМЕН ЖӘНЕ БУЛКІЛДЕУІНСІЗ САЛЫСТЫРУ}

Р.Т. Пинзон, Ф. Бувана

Неврология бөлімі, Медицина мектебі, Дута Ваканның Христиан мектебі, Джокьякарта, Индонезия

\section{ТҰЖЫРЫМДАМА}

Кіріспе: Жүрекше бүлкілдеу инсульт қаупін ұлғайтады және инсульттің жайсыз нәтижесіне алып келеді. Осы зерттеудің негізгі мақсаты ишемиялық инсультке жүрекше бүлкілдеуімен және бүлкілдеусіз шалдыққан пациенттердің клиникалық нәтижесін салыстыру.

Әдістері: Осы ретроспективті когортты зерттеуде Бетесд, Джокьякарта, Индонезия ауруханаларының электронды медициналық карталары және электронды инсульт тізілімінен алынған қайталама деректер қолданылды. Деректер 2017 жылдан бастап 2018 жылға дейінгі аралықта жинақталды. Жүрекше бүлкілдеуінің инсульт ұстамасы кезінде және аурудың қатты өршу кезінде болуы стандартты электрокардиограммамен дәлелденді. Зерттеудің негізгі нәтижелері аурухана ішілік өлімді, Ранкиннің түрлендірілген шкаласы (mRS)бойынша мүгедектенуді және ауруханаға жату ұзақтығын қамтыды. Біз маңыздылық деңгейі 0,05 болатын SPSS 20 бағдарламасын қолдандық.

Нәтижелері: Ишемиялық инсультке шалдыққан 1688 пациенттердің 45 -де (2,67\%) жүрекше бүлкілдеуі болды. Жүрекше бүлкілдеуі бар пациенттердің 51,11\% ерлер және 82,22\% 60 жастан асқандар болды. Инсультке және жүрекше бүлкілдеуіне шалдыққан пациенттер тобының өлімі 18 пациент (40.0\%), 37 пациент (84.4\%) жайсыз функционалдық нәтиже (mRS $\geq 2)$ көрсетті және олардың ауруханада емделу ұзақтығы 6 (0-41) күнді құрады. Бивариантты талдау инсульті бар және жүрекше бүлкіндеуінсіз пациенттер тобына қарағанда, инсультке және жүрекше бүлкілдеуіне шалдыққан пациенттер тобы аурахана ішінде орын алатын өліммен жоғары дәрежеде байланысты (RR: 2.11; 95\% CI: 1.09-2.22; p: 0.001), мүгедектенудің нашар деңгейімен (RR: 2.09; 95\% Cl: 1.92-2.32; p: 0.001) және ұзақ емделу мерзімімен байланысты (6 (041) vs 4 (0-14), р:0.001) екенін көрсетті.

қорытынды: Жүрекше бүлкілдеу инсульттің нәтижесімен байланысты. Мұқият кардиологиялық тексеру және тиісті ем ишемиялық инсультке және жүрекше бүлкілдеуіне шалдыққан науқастардың жағдайын жақсарту үшін қажет.

Негізгі сөздер: жүрекше бүлкілдеуі, ишемиялық инсульт, салыстыру, клиникалық нәтижесі 


\section{СРАВНЕНИЕ КЛИНИЧЕСКОГО ИСХОДА ИШЕМИЧЕСКОГО ИНСУЛЬТА С ФИБРИЛЛЯЦИЕЙ ПРЕДСЕРДИЙ И}

\section{БE3 HEE}

P.Т. Пинзон, Ф. Бувана Rizaldy

Отделение неврологии, Школа медицины, Христианский университет Дута Вакана, Джокьякарта, Индонезия

\section{PЕЗЮМЕ}

Введение: Фибрилляция предсердий увеличивает риск инсульта и приводит к неблагоприятным исходам инсульта. Основной задачей настоящего исследования явилось сравнение клинического исхода у пациентов с ишемическим инсультом с фрибрилляцией предсердий и без нее.

Методы: В настоящем ретроспективном когортном исследовании использовались вторичные данные из электронных медицинских карт и электронного Реестра инсульта больницы Бетесда, Джокьякарта, Индонезия. Данные были собраны в период с 2017 по 2018 годы. Присутствие фибрилляции предсердий при приступе инсульта и во время острой фазы было подтверждено стандартной электрокардиограммой. Основные результаты исследования включали внутрибольничную смертность, инвалидность по модифицированной шкале Ранкина (mRS) и длительность госпитализации. Мы использовали программу SPSS 20 с уровнем значимости 0,05.

Результаты: Из 1688 пациентов с ишемическим инсультом, у 45 (2,67\%) была фрибрилляция предсердий. 51,11\% пациентов с фрибрилляцией предсердий были мужчины и 82,22\% возрастом более 60 лет. Смертность группы пациентов с инсультом и фибрилляцией предсердий составила 18 пациентов (40.0\%), 37 пациентов (84.4\%) имели неблагоприятный фрункциональный исход (mRS $\geq 2$ ) и продолжительность их госпитализации составила 6 (0-41) дней. Бивариантный анализ показал, что пациенты группы с инсультом и фибрилляцией предсердий в значительной степени связаны с более высоким уровнем внутрибольничной смертности (RR: 2.11; 95\% Cl: 1.09-2.22; p: 0.001), худшим уровнем инвалидности (RR: 2.09; 95\% Cl: 1.92-2.32; p: 0.001) и длительным сроком госпитализации (6 (0-41) vs 4 (0-14), р:0.001), чем пациенты группы с инсультом и без фибрилляции предсердий.

Заключение: Фибрилляцияпредсердий связана сисходом инсульта. Внимательное кардиологическое обследование и соответствующее лечение необходимы для улучшения неблагоприятного исхода у пациентов с ишемическим инсультом и фибрилляцией предсердий.

Ключевые слова: фибрилляция предсердий, ишемический инсульт, сравнение, клинический исход

\section{Introduction}

Stroke is the second leading cause of death globally and the third leading cause of premature death and disability [1]. Every year, about 795,000 people in the United States have a stroke. About 610,000 of these are first or new strokes, 185,000 are recurrent strokes [2]. Indonesia's Sample Registration System (SRS) in 2014 showed that stroke was the leading cause of death, which amounted to $21.1 \%$ of all causes of death for all age groups [3].

Atrial fibrillation, the most common sustained cardiac arrhythmia in the general population, affects about $1 \%$ of adults, is the most common cause for cardio embolic stroke and is a risk factor for future cerebrovascular diseases [4]. The prevalence of AF in the general population increases substantially with age, ranging from $0.1 \%$ in those aged $<55$ years to $9 \%$ in those aged $\geq 80$ years [5]. Observational studies (multinational MONICA MONitoring of trends and determinants in CArdiovascular disease) in the urban population in Jakarta, Indonesia found an AF incidence of $0.2 \%$ with a ratio of men and women $3: 2.4$. In addition, there was a significant increase in the percentage of elderly population in Indonesia which is $7.74 \%$ (in 2000-2005) to $28.68 \%$ (WHO estimate for 2045-2050) [6].

Atrial fibrillation (AF) confers a 5- to 6-fold increased risk for ischemic stroke [7]. Research conducted by Wibisono (2012), the risk of ischemic stroke with atrial fibrillation increased 8.5 times greater than ischemic stroke patients without atrial fibrillation [8]. A meta-analysis study involving 32 studies in 5038 patients, found $11 \%$ of ischemic stroke patients detected having atrial fibrillation during electrocardiographic examination [9]. The prevalence of AF among patients with ischemic stroke vary between $15 \%$ and $38 \%$ and the true proportion may be even higher because of difficulties in detection of intermittent, silent AF [10].

Modified Rankin Scale is one of several instruments for measuring the clinical outcome of stroke patients that are often used by health practitioners. Ischemic stroke patients with atrial fibrillation have poor clinical outcomes compared to patients without comorbid AF. Survivor stroke with AF had a greater disability at 7,28 and 90 days following the event than those with non-AF stroke $(\mathrm{P}<0.001)$ [11].

The studies about correlate atrial fibrillation in ischemic stroke with length of stay and functional outcome in Indonesia are very limited. The understanding of risk factors especially atrial fibrillation disease can help the clinician for further management. The primary concern of this study was to compare the clinical outcome of ischemic stroke patients with atrial fibrillation and without atrial fibrillation.

\section{Materials and methods Design}

The design of this study was retrospective cohort that used secondary data recorded in the Bethesda Hospital Yogyakarta Stroke Registry from January 2017 until November 2018. The primary outcome of the study was in-hospital mortality, disability measured by modified Rankin Scale (mRS), and length of stay. We only used complete data. Incomplete data were excluded from the study.

\section{Study population}

The study population of this study were all ischemic stroke patients at Bethesda Hospital in Yogyakarta from January 2017 until November 2018 that confirmed with clinical and CT (computed tomography) scan of the head. The inclusion criteria were as follows: Ischemic stroke patients and complete data. We excluded patients with a incomplete data.

\section{Variables}

The dependent variable in this study is in-hospital mortality, disability measured by modified Rankin Scale (mRS), and length of stay. Disability status was defined as limitations in performing activities and on this basis the subjects were differentiated into those poor functional outcome and good functional outcome. Disability status was measured on a modified Rankin score (mRS) scale [12]. Subjects with good functional outcome included subjects who were no symptoms, no significant disability and slight disability (mRS score 0,1 and 2). Subjects with poor functional outcome included subjects with moderate disability, moderately severe disability, severe disability with a home care program, and death (mRS score 3 to 6).

The Independent variables were atrial fibrillation. Group divided into ischemic stroke patients with history of atrial fibrillation group and ischemic stroke patients without history of atrial fibrillation group. Atrial fibrillation was present if the patient was previously diagnosed by a cardiologist or if the 
arrhythmia was found on a short ECG record performed on admission.

The data about clinical characteristics profile consist of comorbidities, stroke risk factors, drug therapy used for subject characteristics.

\section{Ethic}

This study used secondary data. Research Ethics Committee of Duta Wacana Christian University School of Medicine had approved the study. Ethical clearance for conducting the study was obtained from the ethic committee, Duta Wacana Christian University School of Medicine Yogyakarta, Indonesia.

\section{Statistical Analysis}

The data were presented in descriptive and analytic way. We used RR (Relative Ratio) and 95\% Confidence Interval to show the comparison. We used SPSS version 20 to calculate the significance level $(\mathrm{p}<0,05 \%)$.

\section{Results}

Among 1688 patients with ischemic stroke in the Bethesda Hospital Yogyakarta Stroke Registry from January 2017 until November 2018, 45 (2.67\%) had AF. Among the patients with atrial fibrillation $51.11 \%$ were male and $48.89 \%$ female. $82.22 \%$ patients with atrial fibrillation were more than 60 years old. In the atrial fibrillation group $(+) 9(20 \%)$ had hypertension, $7(15.56 \%)$ had Ischaemic heart disease and 17 (37.78) had dyslipidemias (Table 1).

Table 2 shows that there was showed significant associations between the presence of AF and hypertension, ischemic heart disease and dyslipidemia.

Table 3 shows that $45(2.67 \%)$ ischemic stroke patients with atrial fibrillation. $15,56 \%$ patients with AF had $\mathrm{mRS}<2$ and $84,44 \%$ had $m R S \geq 2$.
Characteristics of ischemic stroke patients with atrial fibrillation and without atrial fibrillation.

\begin{tabular}{|c|c|c|}
\hline Characteristics & $\begin{array}{l}\text { Atrial fibrillation }(+) \\
\mathrm{N}=45(\%)\end{array}$ & $\begin{array}{l}\text { Atrial fibrillation }(-) \\
\mathrm{N}=1643(\%)\end{array}$ \\
\hline \multicolumn{3}{|l|}{ Sex } \\
\hline Male & $23(51.11)$ & $1012(61.60)$ \\
\hline Female & $22(48.89)$ & $631(38.40)$ \\
\hline \multicolumn{3}{|l|}{ Stroke Ever } \\
\hline First stroke & $35(77.78)$ & $1291(78.58)$ \\
\hline Recurrent stroke & $10(22.22)$ & $352(21.42)$ \\
\hline \multicolumn{3}{|l|}{ Comorbidity } \\
\hline \multicolumn{3}{|l|}{ Hypertension } \\
\hline Yes & $9(20)$ & $692(42.11)$ \\
\hline No & $36(80)$ & $951(57.89)$ \\
\hline \multicolumn{3}{|c|}{ Ischaemic heart disease } \\
\hline Yes & $7(15.56)$ & $70(4.27)$ \\
\hline No & $38(84.44)$ & $1573(95.73)$ \\
\hline \multicolumn{3}{|l|}{ Dyslipidemia } \\
\hline Yes & 17 (37.78) & $573(34.88)$ \\
\hline No & $28(62.22)$ & $1070(65.12)$ \\
\hline \multicolumn{3}{|c|}{ Drug Therapy } \\
\hline \multicolumn{3}{|c|}{ Anticoagulant therapy } \\
\hline Yes & $2(4.44)$ & $199(12.11)$ \\
\hline No & $43(95.56)$ & $1444(87.89)$ \\
\hline \multicolumn{3}{|c|}{ Antihypertensive drugs } \\
\hline Yes & $7(15.56)$ & $524(31.90)$ \\
\hline No & $38(84.44)$ & $1119(68.10)$ \\
\hline \multicolumn{3}{|l|}{ Antiplatelet drugs } \\
\hline Yes & $43(95.56)$ & $1507(91.72)$ \\
\hline No & $2(4.44)$ & $136(8.28)$ \\
\hline \multicolumn{3}{|l|}{ Statin drugs } \\
\hline Yes & $22(48.89)$ & $842(51.24)$ \\
\hline No & $23(51.11)$ & $801(48.76)$ \\
\hline
\end{tabular}

Table 2 Comparison of baseline characteristics of ischemic stroke patients with atrial fibrillation and without atrial fibrillation.

\begin{tabular}{|c|c|c|c|}
\hline \multirow[t]{2}{*}{ Characteristics } & \multicolumn{2}{|l|}{ Ischemic Stroke } & \multirow[t]{2}{*}{$\mathrm{p}$ Value } \\
\hline & $\begin{array}{l}\text { Atrial fibrillation }(+) \\
(\%)\end{array}$ & $\begin{array}{l}\text { Atrial fibrillation }(-) \\
(\%)\end{array}$ & \\
\hline \multicolumn{4}{|l|}{ Sex } \\
\hline Male & $23(51.11)$ & $1012(61.60)$ & 0.154 \\
\hline \multicolumn{4}{|l|}{ Comorbidity } \\
\hline Hypertension & $9(20)$ & $692(42.11)$ & 0.001 \\
\hline Ischaemic heart disease & $7(15.56)$ & $70(4.27)$ & 0.001 \\
\hline Dyslipidemia & $17(37.78)$ & $573(34.88)$ & 0.001 \\
\hline \multicolumn{4}{|l|}{ Drug Therapy } \\
\hline Anticoagulant therapy & $2(4.44)$ & $199(12.11)$ & 0.117 \\
\hline Antihypertensive drugs & $7(15.56)$ & $524(31.90)$ & 0.020 \\
\hline Antiplatelet drugs & $43(95.56)$ & $1507(91.72)$ & 0.355 \\
\hline Statin drugs & $22(48.89)$ & $842(51.24)$ & 0.755 \\
\hline
\end{tabular}

Table 3 Association of ischemic heart disease with clinical outcomes.

\begin{tabular}{|c|c|c|c|c|}
\hline \multirow[t]{8}{*}{ Atrial fibrillation } & \multicolumn{2}{|l|}{ Disability } & \multirow[t]{2}{*}{$\mathrm{RR}$} & \multirow[t]{2}{*}{$\mathrm{p}$ Value } \\
\hline & mRS $<2$ (Good) & $\mathrm{mRS} \geq 2$ (Worse) & & \\
\hline & $7(15.56 \%)$ & $38(84.4 \%)$ & $2.09(1.92-2.32)$ & 0.001 \\
\hline & \multicolumn{2}{|l|}{ Mortality } & & \\
\hline & Yes & No & & \\
\hline & $18(40 \%)$ & $27(60 \%)$ & $2.11(1.09-2.22)$ & 0.001 \\
\hline & \multicolumn{2}{|l|}{ Length of stay } & & \\
\hline & 6 (0-41 days) & 0.001 & & \\
\hline
\end{tabular}


While $75,83 \%$ patients without AF had $\mathrm{mRS}<2$ and 24,16 $\%$ had $m R S \geq 2$. There was a significantly different outcome between patient with AF and without AF (RR: 2.09; 95\% CI: 1.92-2.32; p: 0.001). The mortality and prolonged hospitalization were more common in ischemic stroke patients with AF group. Bivariate analysis showed stroke patients with AF group was worse disability (RR: 2.11; 95\% CI: $1.09-2.22$; p: 0.001) and prolonged length of stay [6 (0-41 days) vs 4 ( 0 -14 days) pValue $0.001]$ than in stroke patients without atrial fibrillation group.

\section{Discussion}

The main purpose of this study was to compare clinical outcomes of ischemic stroke patients with atrial fibrillation and without atrial fibrillation. The present study there was association between atrial fibrillation in ischemic stroke with mortality, disability and length of stay in hospital. Ischemic stroke patients with atrial fibrillation disease was associated with higher mortality and poor functional outcome in acute ischemic stroke patients.

Ischaemic stroke risk rises with the increasing cardiovascular risk factors. Atrial fibrillation incrementally contributes to the risk for ischaemic stroke with increasing age and multiple cardiovascular risk factors [13]. This study found that significant associations between the presence of AF and hypertension $(p=0.001)$, ischemic heart disease $(p=0.001)$, dsylipidemia $(\mathrm{p}=0.010)$. This result was also similar to previous studies that atrial fibrillation has been strongest associations with hypertension, ischemic heart disease and dsylipidemia. Hypertension (HTN) is the commonest cardiovascular comorbidity related to atrial fibrillation with $49-90 \%$ of AF patients included in clinical trials having a previous history of HTN. Elevated blood pressure has been one of the strongest predictors of the development of AF and HTN per se increases the risk of AF by 2-fold [15]. Cardiac injury may cause atrial dysfunction or cardiomiopathy, which signifies an increased risk of Ischemic Stroke. Ischemic heart disease and myocardial infarction were common cardiac source of embolic stroke, accounting for up to $30 \%$ [16]. Dyslipidemia associated with atrial fibrillation by increased risk of ischemic heart disease [13].

This study found that, disability was shown to be significantly higher for 45 patients with AF than the nonAF group (84.44\% vs $24.16 \%$ ). Similarly, in previous study ischemic stroke patients following an atrial fibrillation disease had increased disability $[14,17]$. AF was clearly associated with an increased risk of severe neurological deficits. Patients with AF have more severe stroke than stroke patient without AF because the pathogenetic mechanism of stroke. First, strokes in patients with AF may chiefly be cardioembolic, which causes a sudden occlusion of large cerebral arteries without sufficient collateral blood flow, resulting in more severe strokes. Several studies have reported that stroke patients with AF more often have large cortical infarcts on computed tomography, and less frequently have lacunar infarction compared with patients without AF [18-19]. Second, a previous study found a significant reduction in hemispheric cerebral blood flow in patients with AF compared with those with sinus rhythm. The effect of the decreased hemispheric cerebral blood flow may contribute to the development of large infarcts and neurological severity in patients with AF [20].

The mortality were more common in ischemic stroke patients with AF group than the non-AF group. This study was consistent with the results of previous research [21-23]. This is fact that patients with AF have more death than without AF. First, atrial fibrillation prevalence increases with age, making it the most common arrhythmia in patients older than 65 years. Previous studies have indicated that inequalities may exist in the quality of care offered to patients with stroke in particular elderly patients have been reported to be less likely to receive adequate treatment and care [24]. Second, heart diseases are more frequent in patients with AF than without AF. Tomita et al reported that $77 \%$ of 2677 patients with AF had heart diseases such as hypertensive heart disease, ischaemic heart disease, valvular heart disease, sick sinus syndrome, and cardiomyopathy [2527]. Three, risk of fatal hemorrhage conferred by antithrombotic therapy, the causes of death in patients with atrial fibrillation [28].

Length of stay in ischemic stroke with AF group was longer than length of stay in ischemic stroke without AF group (6 (0-41) vs 4 (0-14) days). Similarly, in previous study ischemic stroke patients following an atrial fibrillation disease had prolong hospital stay [29-30]. An increased length of stay among patients with atrial fibrillation may be due to the higher risk of in-hospital medical complications, which will require further treatment and care before the patient can be discharged. The Austrian Stroke Registry reported that atrial fibrillation was associated with an increased risk of pneumonia and urinary tract infection [31].

The limitation of our study was the short-term follow up. We only observed the in hospital mortality and in hospital disability. Further studies should have long-term outcome followup to know long-term mortality and disability. The use of electronic stroke registry and the fact that the types of variable listed in the electronic stroke registry were relatively complete were the strength of this study.

\section{Conclusion}

Ischemic stroke patients with atrial fibrillation was associated with higher in hospital mortality, worse disability, prolonged hospitalization than in ischemic stroke patients without atrial fibrillation. Careful cardiac evaluation and appropriate treatment are needed to improve the poor outcomes in patients with ischemic stroke and AF.

Disclosures: There is no conflict of interest for all authors.

\section{Authors Contribution:}

RP - Concept and design of the study, manuscript preparation, statistically analyzed and interpreted, critical revision of the manuscript.

FB - Concept and design of the Study, collected data, preparing first draft of manuscript, critical revision of manuscript and review of the study.

Source of Support: Nil, Conflict of Interest: None declared.

\section{References}

1. Chin JH and Vora N. The global burden of neurologic diseases. Neurology. 2014; 83(4): 349-351. https://doi.org/10.1212/ WNL.0000000000000610

2. Benjamin EJ, Blaha MJ, Chiuve SE. American Heart Association Statistics Committee and Stroke Statistics Subcommittee: a report from the American Heart Association. Circulation. 2018; 135:e229-e445. https://doi.org/10.1161/CIR.0000000000000558 
3. P2PTM Kemenkes RI. Germas Cegah Stroke [In Indonesia]. 2018; Available from www.p2ptm.kemenkes.go.id.

4. Go AS, Hylek EM, Phillips KA, Chang Y,Henault LE, Selby JV, Singer DE: Prevalence of diagnosed atrial fibrillation in adults: national implications for rhythm management and stroke prevention: the Anticoagulation and Risk Factors in Atrial Fibrillation (ATRIA) Study. JAMA. 2001; 285: 2370-2375 https://doi.org/10.1001/jama.285.18.2370

5. XDeng YX, Wang YL, Gao BQ, Wang CX, Zhao XQ, Liu LP, Wang AX, Zhou Y, Liu GF, Du WL, Zhang N, Jing J, Meng X, et al. Age Differences in Clinical Characteristics, Health care, and Outcomes after Ischemic Stroke in China. CNS Neuroscience \& Therapeutics. 2012; 18:819-26. https://doi.org/10.1111/j.1755-5949.2012.00378.x

6. Indonesian Heart Association. Guidelines for Management of Atrial Fibrillation. Edition 1; 2014.

7. Romero JR, Wolf PA. Epidemiology of stroke: legacy of the Framingham Heart Study. Glob Heart. 2013; 8:67-75. https://doi. org/10.1016/j.gheart.2012.12.007

8. Wibisono A. Associations between Atrial Fibrillation and Ischemic Stroke in Moewardi General Hospital [Thesis] Surakarta: Faculty of Medicine Muhammadiyah Surakarta; 2012.

9. XKishore A, Vail A, Majid A, Dawson J, Lees KR, Tyrrell PJ, et al. Detection of atrial fibrillation after ischemic stroke or transient ischemic attack: a systematic review and meta-analysis. Stroke. 2014; 45:520-526. https://doi.org/10.1161/STROKEAHA.113.003433

10. Friberg L, Rosenqvist M, Lindgren A, Terent A, Norrving B, Asplund K. High Prevalence of Atrial Fibrillation Among Patients With Ischemic Stroke. Stroke AHA Journal. 2014; 45:2599-2605 https://doi.org/10.1161/STROKEAHA.114.006070

11. Hannon N, Sheehan O, Kelly L, Marnane M, Merwick A, Moore A, Kyne L, Duggan J, Moroney J, Daly L, Harris D, Horgan G, Furie K. Stroke Associated with Atrial Fibrillation-Incidence and Early Outcomes in the North Dublin Population Stroke Study. Journal of Cerebrovascular Disease. 2010; 29:43-49. https://doi.org/10.1159/000255973

12. Banks J.L., Marotta C.A. Outcomes Validity and Reliability of the Modified Rankin Scale: Implications for Stroke Clinical Trials. Stroke. 2007; 38:1091-1096. https://doi.org/10.1161/01.STR.0000258355.23810.c6

13. Guo Y, Wang H, Tian Y, Wang Y, Lip GY. Multiple Risk Factors and Ischaemic Stroke in the Elderly Asian Population With and Without Atrial Fibrillation. An analysis of 425,600 Chinese Individuals Without Prior Stroke. Thromb Haemost. 2016; 115:184-192 https://doi. org/10.1160/TH15-07-0577

14. Akanksha W, Paramdeep K, Gagandeep S, Rajinder B, Birinder P, Monika S. Clinical features, Risk factors, and Short-term Outcome of Ischemic Stroke, in Patients with Atrial Fibrillation: Data from a population-based study. Ann Indian Acad Neurol. 2017; 20:289-93. https://doi.org/10.4103/aian.AIAN_16_17

15. Lip GY. Atrial Fibrillation in Patients with Hypertension: Trajectories of Risk Factors in Yet Another Manifestation of Hypertensive Target Organ Damage. Hypertension 2016; 68:544-545. https://doi.org/10.1161/HYPERTENSIONAHA.116.07901

16. Yaghi S, Pilot M, Song C. Ischemic Stroke Risk After Acute Coronary Syndrome. J Am Heart Assoc. 2016; 5(7):e002590. https://doi. org/10.1161/JAHA.115.002590

17. Mallick AK, Ali MA, Kafiluddin M, Amin MP, Kundu PK, Alahi M, Yusuf N. Study on outcome of ischemic stroke patient with atrial fibrillation. KYAMC Journal. 2018; 8(2). https://doi.org/10.3329/kyamcj.v8i2.35696

18. Cerebral Embolism Task Force. Cardiogenic brain embolism. Arch Neurol.1986; 43:71-84. https://doi.org/10.1001/ archneur.1986.00520010065026

19. Hahne K, Mönnig G, Samol A. Atrial fibrillation and silent stroke: links, risks, and challenges. Vascular Health and Risk Management. 2016; 12:65-74. https://doi.org/10.2147/VHRM.S81807

20. Lavy S, Stern S, Melamed E. Effect of chronic atrial fibrillation on regional cerebral blood flow. Stroke. 1980; 11:35-8. https://doi. org/10.1161/01.STR.11.1.35

21. Saposnik G, Gladstone D, Raptis R, Zhou L, Hart R. Atrial Fibrillation in Ischemic Stroke Predicting Response to Trombolysis and Clinical Outcomes. Stroke AHA Journal. 2013; 44:99-104. https://doi.org/10.1161/STROKEAHA.112.676551

22. McGrath, Kapral M, Fang J, Eikelboom J, O’Conghaile A, Canavan M, O’Donnell M. Association of Atrial Fibrillation with Mortality and Disability after Ischemic Stroke. Neurology. 2013; 81:825-832 https://doi.org/10.1212/WNL.0b013e3182a2cc15

23. Lie, Zhao X, Wang C, Liu L, Liu G, Wang Y, Wang C, Jing J, Wang YJ.Risk factors for poor outcome and mortality at 3 months after the ischemic stroke in patients with atrial fibrillation. J Stroke Cerebrovasc Dis. 2013; 22(8):e419-25. https://doi.org/10.1016/j.jstroke cerebrovasdis.2013.04.025

24. Bhalla A, Grieve R, Tilling K, Rudd AG, Wolfe CD. Older stroke patients in Europe: stroke care and determinants of outcome. Age Ageing. 2004; 33(6):618-624. https://doi.org/10.1093/ageing/afh219

25. Tomita F, Kohya T, Sakurai M, et al; Hokkaido Atrial Fibrillation Study Group. Prevalence and clinical characteristics of patients with atrial fibrillation: analysis of 20,000 cases in Japan. Jpn Circ J. 2000; 64:653-8. https://doi.org/10.1253/jcj.64.653

26. Gustafsson C, Britton M. Pathogenetic mechanism of stroke in non-valvular atrial fibrillation: follow-up of stroke patients with and without atrial fibrillation. J Intern Med. 1991; 230:11-16. https://doi.org/10.1111/j.1365-2796.1991.tb00400.x

27. Kaarisalo MM, Immonen-Raiha P, Marttila RJ. Atrial fibrillation and stroke. Mortality and causes of death after the first acute ischemic stroke. Stroke. 1997; 28:311-15. https://doi.org/10.1161/01.STR.28.2.311

28. Fauchier L, Villejoubert O, Clementy N, Bernard A, Pierre B, Angoulvant D, Ivanes F, Babuty D. Causes of Death and Influencing Factors in Patients with Atrial Fibrillation. The American Journal of Medicine. 2016; 129:-128. https://doi.org/10.1016/j.amjmed.2016.06.045

29. Kruchov S, Frost L, Eagle K, Paaske S. Atrial Fibrillation in Patients with Ischemic Stroke: A Population-based Study. Clinical Epidemiology. 2009; 55-65. https://doi.org/10.2147/CLEP.S4794

30. Kimura K, Minematsu K, Yamaguchi T. Atrial fibrillation as a predictive factor for severe stroke and early death in 15831 patients with acute ischaemic stroke. J Neurol Neurosurg Psychiatry. 2005; 76:679-683. https://doi.org/10.1136/jnnp.2004.048827

31. Steger C, Pratter A, Martinek-Bregel M, et al. Stroke patients with atrial fibrillation have a worse prognosis than patients without: data from the Austrian Stroke registry. Eur Heart J. 2004; 25(19):1734-1740. https://doi.org/10.1016/j.ehj.2004.06.030

How to cite this article: Rizaldy Taslim Pinzon, Fransiscus Buwana. The clinical outcome comparison of ischemic stroke with and without atrial fibrillation. J Clin Med Kaz. 2019; 2(52):37-41 